\title{
Temperature and Age of Plant Affect Resistance in Peach-Almond Hybrid Rootstock Infected with Meloidogyne javanica
}

\author{
Jordi Canals ${ }^{1}$ and Jorge Pinochet ${ }^{2}$ \\ Departamento de Patología Vegetal, Institut de Recerca i Technologia \\ Agroalimentàries, Carretera de Cabrils s/n 08348, Cabrils, Barcelona, \\ Spain
}

\author{
Antonio Felipe ${ }^{3}$ \\ Servicio de Investigaciones Agrarias, Apartado 727, 50080 Zaragoza, \\ Spain
}

\section{Additional index words. Prunus}

\begin{abstract}
The influence of temperature and age of the plant was determined on nematode reproduction on a susceptible almond (Prunus amygdalus Batsch.) and on a resistant peach-almond hybrid $(P$. persica Stok. $x$. amygdalus Batsch.) rootstock inoculated with Meloidogyne javanica (Treub) Chitwood. Experiments were conducted under greenhouse conditions in heated and unheated sand beds. 'Garrigues' almond inoculated with 3000 nematodes per plant showed extensive galling, high final nematode population levels, and high counts of nematodes per gram of root at 27 and 32C. The hybrid G $x$ N No. 1 showed minimal galling and reproduction at $27 \mathrm{C}$ but higher levels of galling and final population and nematode counts per gram of root at 32C, suggesting a partial loss of resistance with temperature increase. One-month-old and 1-year-old plants of 'Garrigues' were susceptible following inoculation with 2000 nematodes per plant, although plantlets (l-month) were significantly more affected. Plantlets of hybrid G X N No. 1 were also susceptible, but 1 -year-old plants were resistant. Resistant genotypes ( $\mathrm{G} \times \mathrm{N}$ selections) seem to require root tissue maturation before expressing full resistance.
\end{abstract}

The expression of resistance to nematodes can be modified by environmental conditions that affect defense mechanisms in many crop species (Canto-Saenz, 1985; Rohde, 1972; Stover and Buddenhagen, 1986). Temperature, nutritional status, soil $\mathrm{pH}$, and plant age are some of the major factors affecting resistance expression to nematode-infected plants (Ammati et al., 1986; Davide and Triantaphyllou, 1967; Dropkin, 1963; Jaffee and Mai, 1979; McClure et al., 1974; Sarah et al., 1991). Therefore, even without taking into account the nematode pathogenic vari-

Received for publication 4 Mar. 1992. Accepted for publication 10 June 1992. This work was financed by the Instituto National de Investigaciones Agrarias, INIA, Grant no. 8528. The cost of publishing this paper was defrayed in part by the payment of page charges. Under postal regulations, this paper therefore must be hereby marked advertisement solely to indicate this fact.

${ }^{1}$ Graduate Assistant.

${ }^{2}$ Research Nematologist.

${ }^{3}$ PIant Breeder. ability, the assessment of resistance expression in plant material supposedly resistant after screening tests should consider additional stress evaluations to correlate quick and efficient tests carried out with plantlets (seedlings, in vitro or vegetatively propagated plantlets) with field performance. From the practical standpoint, a more rigorous months after inoculation with 3000 nematodes per plant. differ according to Student $t$ test $(P=0.05)$.

${ }^{\mathrm{y}}$ Total number of nematodes per plant.

${ }^{\mathrm{x}} \mathrm{S}=$ susceptible; $\mathrm{R}=$ resistant. evaluation will allow the detection of germplasm that would maintain desired nematode resistance under environmental stress,

Recent studies in Spain indicate that some experimental peach-almond hybrids $(\mathrm{G} \times \mathrm{N})$ show a high level of resistance to Meloidogyne incognita (Kofoid and White), M. armaria (Neal) Chitwood, and $M$. javanica (Marull et al., 1991; Marull and Pinochet, 1991). These $\mathrm{G} \times \mathrm{N}$ selections were derived from crosses between the almond (female parent) 'Garfi' and the root-knot-nematoderesistant peach (male parent) 'Nemared' (Ramming and Tanner, 1983). Besides the nematode-resistant features, most $\mathrm{G} \times \mathrm{N}$ selections are vigorous, have red leaves, show good compatibility with almond varieties, and are adapted to calcareous soils. In spite of these encouraging results, further testing is required to verify that the desirable root-knotnematode-resistant features are maintained under environmental stress, such as those that may affect nursery material in Spain and other warm Mediterranean environments. The purpose of this research was to study the influence of soil temperature and age of plant tissue on the level of resistance of $\mathrm{G} \times \mathrm{N}$ No. 1 rootstock to root-knot nematodes.

Seeds of the almond rootstock ' $\mathrm{Ga}$ rrigues', together with hardwood and herbaceous cuttings of the peach-almond hybrid, G x N No. 1, were supplied by the Programa de Fruticultura of the Servicio de Investigación Agraria (SIA) of the Diputación General de Aragón in Zaragoza, Spain. Seeds of 'Garrigues' were treated with a solution of copper oxychloride for $24 \mathrm{~h}$, rinsed with running water to eliminate traces of the fungicide, and stratified at $4 \mathrm{C}$ for 60 days in perlitefilled trays. These were then moved to a greenhouse to induce seed germination. The peach-almond hybrids were propagated from hardwood and herbaceous cuttings. Cuttings were treated for $5 \mathrm{sec}$ with a $50 \%$ ethanol solution that contained $2000 \mathrm{ppm}$ of indole butyric acid. Cuttings to be rooted were then

Table 1. Influence of soil temperature on root galling and reproduction of Meloidogyne javanica on 'Garrigues' almond (susceptible) and G x N No. 1 peach-almond hybrid (resistant) rootstocks 3

\begin{tabular}{|c|c|c|c|c|c|}
\hline Rootstock & $\begin{array}{c}\text { Temp } \\
\left({ }^{\circ} \mathrm{C}\right)\end{array}$ & $\begin{array}{l}\text { No. } \\
\text { galls/plant }\end{array}$ & $\begin{array}{c}\text { Final nematode } \\
\text { population } \\
\text { (roots and soil)y }^{y}\end{array}$ & $\begin{array}{c}\text { Nematodes/ } \\
\text { g root }\end{array}$ & $\begin{array}{l}\text { Resistance } \\
\text { rating }\end{array}$ \\
\hline Garrigues & $\begin{array}{l}27 \\
32\end{array}$ & $\begin{array}{l}99 \mathrm{a} \\
67 \mathrm{a}\end{array}$ & $\begin{array}{l}46,200 \mathrm{a} \\
20,050 \mathrm{a}\end{array}$ & $\begin{array}{l}6,395 \mathrm{a} \\
1,600 \mathrm{~b}\end{array}$ & S \\
\hline$G \times N$ No. 1 & $\begin{array}{l}27 \\
32\end{array}$ & $\begin{array}{r}5 \mathrm{a} \\
31 \mathrm{~b}\end{array}$ & $\begin{array}{r}90 \mathrm{~b} \\
6,210 \mathrm{a}\end{array}$ & $\begin{array}{r}5 \mathrm{~b} \\
145 \mathrm{a}\end{array}$ & $\begin{array}{l}\mathrm{R} \\
\mathrm{S}\end{array}$ \\
\hline
\end{tabular}

${ }_{\mathrm{z}}$ Data are means of seven replications. Arithmetic means are presented, but data were transformed to $\log ,(\mathrm{N}+1)$ for analysis. Means in columns for each rootstock followed by the same letter do not 
Table 2. Response of 'Garrigues' almond (susceptible) and G x N No. 1 peach-almond (resistant) rootstocks of different ages inoculated with 2000 Meloidogyne javanica per plant at 75 and 65 days after inoculation, respectively.

\begin{tabular}{lccccc}
\hline \hline & $\begin{array}{c}\text { Age of } \\
\text { plants } \\
\text { Ronths) }\end{array}$ & $\begin{array}{c}\text { No. } \\
\text { galls/plant }\end{array}$ & $\begin{array}{c}\text { Final ncmatode } \\
\text { population } \\
\text { (soil and roots) }\end{array}$ & $\begin{array}{c}\text { Nematodes/ } \\
\text { g root }\end{array}$ & $\begin{array}{c}\text { Resistance } \\
\text { rating }^{\mathbf{x}}\end{array}$ \\
\hline Garrigues & 1 & $45 \mathrm{a}$ & $14,040 \mathrm{a}$ & $5,370 \mathrm{a}$ & $\mathrm{S}$ \\
$\mathrm{G}$ & 15 & $17 \mathrm{~b}$ & $14,480 \mathrm{a}$ & $470 \mathrm{~b}$ & $\mathrm{~S}$ \\
& 1 & $41 \mathrm{a}$ & $1,430 \mathrm{a}$ & $570 \mathrm{a}$ & $\mathrm{S}$ \\
& 13 & $0 \mathrm{~b}$ & $0 \mathrm{~b}$ & $0 \mathrm{~b}$ & HR \\
\hline
\end{tabular}

${ }^{\mathrm{z}}$ Data are means of eight replications. Arithmetic means are presented, but data were transformed to $\log _{10}(\mathrm{~N}+1)$ for analysis. Means in columns for each rootstock followed by the same letter do not differ according to Student $t$ test $(P=0.05)$.

${ }^{\mathrm{y}}$ Total number of nematodes per plant.

${ }^{\mathrm{x}} \mathrm{S}=$ susceptible; HR = highly resistant.

planted in $200-\mathrm{cm}^{3}$ pots containing a 3 quartz sand : 1 peat mixture $(\mathrm{v} / \mathrm{v})$ previously pasteurized at $80 \mathrm{C}$. Germinated seeds and rooted cuttings were transplanted to 3-liter pots containing a pasteurized sandy loam textured soil $(75 \%$ sand, $12 \%$ silt, $3 \%$ clay; $\mathrm{pH} 7.5$; $<1 \%$ organic matter; and a cation exchange capacity <10 meq/100 g soil). Plants used for temperature studies were kept in the greenhouse for 9 weeks before inoculation, whereas hardwood cuttings and seedlings used in plant age studies had been started the previous year. One-month-old herbaceous cuttings were prepared the 2nd year.

The isolate of $M$. javanica was collected from fig (Ficus carica L.) in Cabrils, Barcelona, Spain. This isolate was increased on tomato (Lycopersicum esculentum Mill. cv. Roma) from single egg mass cultures. Nematode inoculum was prepared by macerating infested tomato roots in a blender for $15 \mathrm{sec}$ in a $0.12 \%$ to $0.15 \% \mathrm{NaOCl}$ solution (Hussey and Barker, 1973). Eggs were concentrated in a $0.025-\mathrm{mm}$ sieve (500 mesh) and rinsed with tap water before inoculation.

Temperature study. Inoculum was adjusted to deliver a suspension of 3000 eggs of $M$. javanica per plant placed in six holes 3 to $4 \mathrm{~cm}$ deep located $3 \mathrm{~cm}$ from the base of the plant. The plants of 'Garrigues' (susceptible) and G x N No. 1 (resistant) rootstocks had uniform growth (10 to 15 leaves). A set of inoculated pots of 'Garrigues' and $\mathrm{G} \times \mathrm{N}$ No. 1 were placed in sand beds and subjected to ambient greenhouse temperature and humidity fluctuations. The other set of inoculated pots was placed in a thermoregulated sand bed and maintained at a mean soil temperature (measured at the center of the pot) of $32 \mathrm{C}$ throughout the study. Soil thermometers that recorded maximum and minimum temperatures were placed in four pots. Three daily readings were made on ambient and soil temperature in heated and unheat sand beds. The total number of root galls, final nematode population per plant [second-stage juveniles (J2) in soil and eggs together with $\mathrm{J} 2$ in roots counted separately and then added], and the number of nematodes per gram of root were assessed 90 days after inoculation (DAI). Nematodes in soil were obtained by removing soil from containers and placing contents in a large pan. Roots were washed free of soil particles in a second pan with a known volume of water.
Contents of both pans were mixed and stirred for $1 \mathrm{~min}$. A $250-\mathrm{cm}^{3}$ subsample of the slurry was obtained, and nematodes were extracted by differential sieving and sugar flotation (Jenkins, 1964).

Nematode extraction from roots was similar to that used for inoculum preparation (Marull et al., 1991). The extra time used to macerate the roots was needed to break lignification present in both rootstocks to free eggs and $\mathrm{J} 2$ embedded in the root tissue. Nematodes were then concentrated using $0.150,0.074$, and $0.025-\mathrm{mm}$ sieves (100, 200 , and 500 mesh, respectively). Root tissue and debris collected on the $0.150-\mathrm{mm}$ sieve were discarded.

Plant age study. Plant material for this study was prepared in 2 years. One-monthold seedlings and 15-month-old plants of 'Garrigues' inoculated with 2000 eggs of $M$. javanica per plant were compared 75 DAI. Mean ambient temperature in the greenhouse during daytime was $27.5 \mathrm{C}( \pm 5 \mathrm{C})$ in this study. Seeds used in the first and 2 nd years were from the same batch. Similarly, 1month-old rooted cuttings and 13-month-old hardwood cuttings of $\mathrm{G} \times \mathrm{N}$ No. 1 with the same inoculum level were compared at 65 DAL Galling and nematode reproduction were assessed at the end of each experiment as described above. Resistance was rated according to the scale suggested by Taylor and Sasser (1978), based on galling and nematode reproduction: HR = highly resistant (nematode invades root but there is little or no reproduction, normally no galling); $\mathrm{R}=$ resistant (limited reproduction with final nematode population lower than initially, incipient galling); $\mathrm{MR}=$ moderately resistant (final population equal or slightly higher than initially, galling scarce although noticeable); $\mathrm{S}=$ susceptible (nematode reproduces well in a short period with abundant galling and egg masses in the roots).

In both studies, plants were watered daily, or as needed, and fertilized with full-strength Hoagland's nutrient solution once a week (Hoagland and Arnon, 1950). In the temperature and the plant age study, each material was replicated seven and eight times, respectively, in a completely randomized design. Data were analyzed by a one-way analysis of variance. Gall index, final nematode population density, and nematodes per gram of root data were $\log _{10}$-transformed (N
$+1)$. Means were compared by Student's $t$ test $(P=0.05)$.

Temperature study. Soil temperature recordings fluctuated between 27.7 and 33.9C (night/day), reaching an average of $31 . \mathrm{K}$ in heated sand beds, whereas in unheated beds, soil in pots fluctuated between 19.8 and $32.1 \mathrm{C}$, averaging $27 \mathrm{C}$. Mean difference between pots in heated and unheated sand beds was 4.8C. 'Garrigues' almond (susceptible) showed extensive galling and a high level of parasitism at both temperatures, although significantly more nematodes were found per gram of roots at $27 \mathrm{C}$. The peach-almond hybrid G x N No. 1 expressed its high level of resistance to the root-knot nematode at 27C. However, it showed a significantly higher number of galls, and final population and number of nematodes per gram of root in pots maintained at $32 \mathrm{C}$ (Table 1). In spite of the visible galling and nematode reproduction at $32 \mathrm{C}$ on $\mathrm{G} \times \mathrm{N}$ No. 1, no egg masses were found in the root systems.

Plant age study. One-month-old and 15month-old 'Garrigues' plants were susceptible, with no differences in the final nematode population (Table 2). However, there was significantly less galling and there were fewer nematodes per gram of root in 15 month-old plants than in 1-month-old plantlets; the latter had a considerably smaller root system. One-month-old plantlets of hybrid G $\mathrm{x} \mathrm{N}$ No. 1 were also susceptible, but 13month-old plants were highly resistant $(\mathrm{Ta}-$ ble 2). Galls of $G \times N$ No. 1 plantlets were considerably smaller ( 2 to $3 \mathrm{~mm}$ in diameter) than those of 'Garrigues' ( 2 to $10 \mathrm{~mm}$ in diameter).

Soil temperature and plant age appear to be two important factors that affect resistance expression in root-knot-nematode-resistant peach rootstocks. Wehunt (1972) reported the influence of temperature on the development of a root-knot species in a resistant Prunus rootstock. In that study, resistant 'Nemaguard' peach inoculated with $M$. incognita showed more galling at 30C than at 25,35 , or $40 \mathrm{C}$. The author concluded that rootstock evaluation should be made at soil temperatures optimal for nematode development. Our findings with $\mathrm{G}$ x N No. 1 inoculated with $M$. javanica indicate similar susceptible host response at $32 \mathrm{C}$ in comparison to $27 \mathrm{C}$ (five incipient galls and no apparent reproduction). A partial loss of resistance in $\mathrm{G} \times \mathrm{N}$ No. 1 to the nematode resulting in larger root galls and a host response at the histological level similar to that found in the susceptible 'Garrigues' rootstock (giant cell formation and nemaiode development) was also observed (unpublished data). Practical implications at the field level could be important in that young and resistant rootstocks established in early spring can be affected in warm soils (30 to 35C during daytime in first $15 \mathrm{~cm}$ of top soil) infested with Meloidogyne spp., such as those that prevail in the peach-growing regions of Murcia, Andalucia, and Extremadura in southern Spain. These results could also explain galling observed in root-knot resistant 'Nemaguard' and 'Nemared' peach rootstocks in 
field plantations in Seville (C. Orero, personal communication).

However, high soil temperatures (mean of 32C) also adversely affected the number of nematodes per gram of root on the susceptible 'Garrigues' rootstock in comparison to $27 \mathrm{C}$, even though there were no significant differences in the final nematode populations at the two temperature regimes. Although, in relative terms, reproduction of $M$. javanica can still be considered as high.

One-month-old G x N No. 1 responded as susceptible when inoculated with M. javanica. In contrast, the same plant material, when 13 months old, was highly resistant. Apparently, this resistant genotype seems to require a physiological maturation process of the root tissues before expressing full resistance against the nematode. Even in the susceptible 'Garrigues', 15-month-old plants showed less tendency to gall and had a considerably lower level of parasitism in comparison to less-lignified 1-month-old plants. These results indicate a high vulnerability of young rootstocks, which is likely to be important in material originating from seedlings, in vitro, or hardwood cuttings transplanted into infested soil during the first 3 to 6 months. 'Garrigues' and the resistant G x N No. 1 apparently can be severely attacked by root-knot nematodes in the initial stages of plant growth but would be less damaged or completely resistant after the first year of growth. It is concluded that plantlets of Prunus at certain stages of development might not be suitable for root-knot nematode rootstock selection procedures, since resistant genotypes could be overlooked due to the lack of full resistance expression in the early stages. The mechanisms involved in the delayed expression are unknown.

\section{Literature Cited}

Ammati, M., I.J. Thomason, and H.E. McKinney. 1986. Retention of resistance to $\mathrm{Me}$ loidogyne incognita in Lycopersicon genotypes at high soil temperature. J. Nematol. 18:491495.

Canto-Saenz, M. 1985. The nature of resistance to Meloidogyne incognita (Kofoid and White, 1919) Chitwood, 1949, p. 225-231. In: J.N. Sasser and C.C. Carter (eds.). An advanced treatise on Meloidogyne. vol. I, Biology and control. North Carolina State Graphics, Raleigh.

Davide, R.G. and G. Triantaphyllou. 1967. Influence of the environment on development and sex differentiation of root-knot nematodes. I. Effect of infection density, age of the host plant and soil temperature. Nematologica 13:102-110.

Dropkin, V.H. 1969. The necrotic reaction of tomatoes and other hosts resistant to Meloidogyne reversed by temperature. Phytopathology 59:1632-1637.

Hoagland, D. and D.I. Arnon. 1950. The water culture method for growing plants without soil. Calif. Agr. Expt. Sta. Circ. 347. Univ. of California, Berkeley.

Hussey, R.S. and K.R. Barker. 1973. A comparison of methods of collecting inocula of Meloidogyne spp. including a new technique. Plant Dis. Rptr. 57:1025-1028.

Jaffee, B.A. and W.F. Mai. 1979. Growth reduction of apple seedlings by Pratylenchus pene- trans as influenced by seedling age at inoculation. J. Nematol. 11:161-165.

Jenkins, W.R. 1964. A rapid centrifugal flotation technique for separating nematodes from soil. Plant Dis. Rptr. 48:692.

Marull, J. and J. Pinochet. 1991. Host suitability of Prunus rootstocks to four Meloidogyne species and Pratylenchus vulnus in Spain. Nematropica 21:185-195.

Marull J., J. Pinochet, S. Verdejo, and A. Soler. 1991. Reaction of Prunus rootstocks to Meloidogyne incognita and $M$. arenaria in Spain. J. Nematol. 23(48):564-569.

McClure, M.A., K.C. Ellis, and E.L. Nigh. 1974. Resistance of cotton to the root-knot nematode Meloidogyne incognita. J. Nematol. 6:17-20.

Ramming, D.W. and O. Tanner. 1983. 'Nemared' peach rootstock. HortScience 18:376.
Rohde, R.A. 1972. Expression of resistance in plants to nematodes. Annu. Rev. Phytopathol. 10:233-251.

Sarah, J.L., B. Osseni, and R. Hugon. 1991. Effect of soil $\mathrm{pH}$ on development of Pratylenchus brachyurus in pineapple roots. Nematropica 21:211-216.

Stover, R.H. and I. Buddenhagen. 1986. Banana breeding: Polyploidy, disease resistance and productivity. Fruits 41:175-191.

Taylor, A.L. and J.N. Sasser. 1978. Biology, identification and control of root-knot nematodes (Meloidogyne species), North Carolina State Univ. Graphics, Raleigh.

Wehunt, E.J. 1972. Influence of temperature on infection of Meloidogyne incognita acrita on 'Nemaguard' peach. Plant Dis. Rptr. 56:305308 . 